5

\title{
The environment and the Swedish public, 1967-1968
}

On 4 December 1967, a group calling itself 'Studentgruppen för främjandet av Naturriktig Kultur' [the Student Group for the Promotion of Nature-compatible Culture] contacted Hans Palmstierna. This newly founded student association sought to prevent the 'plundering and poisoning of nature' by arranging lectures, writing circular letters, and commenting in the daily press. The group's chair, Ulla-Britt Bergman-Holmstrand, wondered if Associate Professor Palmstierna could come to Uppsala some evening in February to give a lecture. Perhaps it might even be possible to arrange a podium debate? ${ }^{1}$

That same day, another Uppsala student named Berth Lundberg wrote with a similar request. He represented the city's Christian student associations, which were planning to conduct a panel debate on environmental destruction. The focus would be on biocides, air and water pollution, and urbanization and stress. In addition to inviting environmental-protection experts, the plan was to invite a theologian, who could 'incorporate the Christian idea of stewardship into the context'. Lundberg stressed that the event was not intended as 'information from experts' but instead aimed at 'normative assessments and opinion formation'.

A week or so earlier, a third student association in Uppsala, the Liberal Club, had contacted Palmstierna, asking if he could come and talk about 'the destruction of nature'. The size of the audience was 'hard to estimate'; but because 'with you as the initial speaker' it would be an 'extremely attractive event', they could count on about

1 Letter from Ulla-Britt Bergman-Holmstrand to Hans Palmstierna, 4 December 1967, 452/3/2 (HP ARBARK).

2 Letter from Berth Lundberg to Hans Palmstierna, 4 December 1967, 452/3/2 (HP ARBARK). 
fifty people. ${ }^{3}$ The Christian students thought they could attract about a hundred. ${ }^{4}$ Palmstierna replied that he would be happy to come to Uppsala and talk, but suggested that the three student associations hold a joint event. At the same time, he also accepted invitations from Studentaftonutskottet [a high-profile student society arranging evening lectures] in Lund, the Department of Education at Stockholm University, the Swedish Society of Psychologists, and a local Rotary club. ${ }^{5}$ This attention from the general public filled him with confidence. On 28 December 1967, he wrote to an American organization called Scientist and Citizen to describe everything that had happened and was about to happen in Sweden, saying, '[t]his last year has been the year when the tide has been turning, I think' ${ }^{6}$

The preserved correspondence from which the above examples were taken is a unique phenomenon. Compared to the collections of other early Swedish environmental debaters, such as Rolf Edberg, those of Hans Palmstierna are of a completely different scope and character. They make it possible to visualize and analyse significant parts of the grassroots activity that followed the major breakthrough of environmental issues in Sweden. From this material, a motley group of actors, organizations, ideas, and initiatives emerges. The letters hence demonstrate that knowledge about the environmental crisis was circulating in Swedish society. Environmental issues were not only being discussed at the Government Offices and the Karolinska Institute. Interest among young students was strikingly high. Both as individuals and as members of associations, actors from this group heeded the warnings of scientists at an early stage. The students were also keen to take the step from knowledge to action. True, their financial resources were modest; but they had plenty of time and a high level of commitment.

3 Letter from Jan Carlsson to Hans Palmstierna, undated 1967, 452/3/2 (HP ARBARK).

4 Letter from Berth Lundberg to Hans Palmstierna, 4 December 1967, 452/3/2 (HP ARBARK).

5 Letter from Stig Lindholm to Hans Palmstierna, 5 December 1967, 452/3/2 (HP ARBARK); Letter from Kerstin Allroth to Hans Palmstierna, 11 December 1967, 452/3/2 (HP ARBARK); Letter from Klas Güettler to Hans Palmstierna, 12 December 1967, 452/3/2 (HP ARBARK); Letter from Vällingby Rotary Club to Hans Palmstierna, 28 December 1967, 452/3/2 (HP ARBARK).

6 Letter from Hans Palmstierna to Virginia Brodine, 28 December 1967, 452/3/2 (HP ARBARK). 
Other actors had greater resources at their disposal. Hans Palmstierna himself was an active Social Democrat, which meant that many organizations with ties to social democracy appear in his correspondence. The most important of these was the cooperative insurance company Folksam, at that time Sweden's largest insurance company. Folksam was just as self-evident a part of the labour movement as trade unions and educational associations. In December 1967, Folksam's youth council decided to launch a nationwide campaign called 'Front mot miljöförstöringen' [A front against environmental destruction]. Palmstierna was commissioned to record films, prepare study materials, and run the campaign. This initiative was the first large-scale attempt in Sweden to turn the growing commitment to the environment into a popular movement. ${ }^{7}$

What also emerges from Palmstierna's correspondence is that the social breakthrough of knowledge functioned like a chain reaction. One person's action led other people to do things, which in turn made more people act. Chains of events like these are, of course, impossible to map in their entirety. In my view, however, they are absolutely crucial when it comes to understanding what a social breakthrough of knowledge is and how it occurs.

Chronologically, this chapter covers December 1967 to midOctober 1968. During this period Hans Palmstierna was constantly on the move. In March, he left the Karolinska Institute for a newly established position at the National Environment Protection Board. That summer, he became head of the Board's research secretariat. In October - a few weeks after the Social Democrats' historic victory of 50.1 per cent of the votes in the election for the Second Chamber [andra kammaren, the lower house of the Riksdag, which was bicameral until 1970] - he was hired by the Environmental Advisory Council to work directly under the government. Concurrently, he was a member of the group that was preparing the Social Democrats' first environmental programme; he travelled all around the country giving lectures; and he participated diligently in the press, radio, and television. However, my aim here is not to map out his activities in detail. Instead, I am using the correspondence - and to some extent press clippings - to gain a picture of everything that was happening around him within a Swedish society which realized that the environment was under threat.

7 Anon., 'Stor ungdomsgiv mot miljöförstörelse', DN, 14 December 1967; Anon., 'Front mot miljöförstöringen i ny ungdomsgiv', Folksam: Organ för kooperativa fackliga försäkringsrörelsen (Folksam), 1 (1968), pp. 4-5. 


\section{The diversity of the commitment to the environment}

On 2 January 1968, Sören Gunnarsson wrote to Hans Palmstierna to remind him that in the previous autumn they had discussed founding an activist group to which 'battle-hungry names' could be attracted. 'What should we do now?' he wondered. 'Can I help?' In reply, Palmstierna described the upcoming Folksam campaign which he was to lead. He explained that 'Folksam has direct, unfettered ties right out into the youth movements, the cooperative movement, ABF [the Workers' Educational Association], and much more'. This was a 'huge complex' whose extent he was only now beginning to grasp. He encouraged Gunnarsson to travel to Stockholm when he had an opportunity, preferably on 30 January when the campaign would be launched. ${ }^{9}$ This exchange reveals how fast ambitions were growing. The small-scale activist group envisioned by Palmstierna at the end of November 1967 had become outdated by January $1968 .{ }^{10}$ Now he wanted to create something much bigger: a popular movement. Nor was he alone in that aim.

In the province of Värmland, a society called 'Vänner av Vänern' [Friends of Lake Vänern] had been formed in the autumn of 1967. Through its campaign entitled 'Rädda Vänern' [Save Lake Vänern], the society had gained significant media attention and rapidly increased its membership. At the beginning of January, it had about 1,000 members. Its chair, one Mr E. Eriksson, emphasized that the group 'had not only spread propaganda and shaped public opinion' but had also lodged three complaints with the Västerbygden Water Court. The society's activities were geared to stopping the contamination of Lake Vänern, repairing the damage already done, and bringing about stricter legislation. Eriksson told Palmstierna that the press described the society as 'a nascent popular movement which is vigorously asserting its ideas'. However, the society was burdened by financial problems. To persuade Palmstierna to become actively involved, Eriksson enclosed a number of press clippings demonstrating its media impact. ${ }^{11}$

8 Letter from Sören Gunnarsson to Hans Palmstierna, 2 January 1968, 452/3/3 (HP ARBARK).

9 Letter from Hans Palmstierna to Sören Gunnarsson, 14 January 1968, 452/3/3 (HP ARBARK).

10 Ibid.

11 Letter from E. Eriksson to Hans Palmstierna, January 1968, 452/3/3 (HP ARBARK). 
The 'Friends of Vänern' initiative was the largest of its kind at this time; but many other associations were also active, albeit on a smaller scale. In the autumn of 1967 , the limnological society Societas Aquatica Lundensis instituted two prizes in Lund: vattenklövern and lortmedaljen [the water clover and the filth medal]. The former was awarded to Hans Palmstierna for his successful information activities; the latter was given to the City of Gothenburg, which pleased Palmstierna very much. He characterized the filth medal as 'wonderfully infuriating'. ${ }^{12}$ Another campaign that was just being launched focused on limiting the birth rate. The initiative came from the World Federalist Movement, part of the peace movement. In early 1968 it launched a Sweden-wide fundraising campaign for the International Planned Parenthood Federation. One of the people involved was Karl-Erik Fichtelius, editor of Människans villkor. He felt that, over the past year in Sweden, the ground had been 'quite well prepared for some practical initiatives'. ${ }^{13}$ Palmstierna contributed by signing a petition, but he declined a request to come to Lund to speak to the peace-political association PAX about environmental destruction. ${ }^{14}$

As organizations, the 'Friends of Vänern' and the World Federalist Movement were highly dissimilar. Whereas the former was interested in the local environment and worked to influence municipal politicians and business leaders, the latter was involved in global politics. Both saw an ally in Hans Palmstierna, but they responded to different aspects of his message. Palmstierna himself moved freely between the various levels. While taking a lively interest in local and national issues, he also sought to establish international contacts, for instance with the American researcher and environmental activist Barry Commoner. ${ }^{15} \mathrm{He}$ was also keen to get Plundring, svält, förgiftning translated into other languages. ${ }^{16}$

12 Letter from Hans Palmstierna to Societas Acquatica Lundensis, 10 January 1968, 452/3/2 (HP ARBARK).

13 Letter from Karl-Erik Fichtelius to Hans Palmstierna, 8 January 1968, 452/3/3 (HP ARBARK).

14 Letter from Björn Hammarberg to Hans Palmstierna, 2 January 1968, 452/3/3 (HP ARBARK); Letter from Hans Regnéll to Hans Palmstierna, 18 February 1968, 452/3/3 (HP ARBARK); Letter from Hans Palmstierna to Hans Regnéll, 25 February 1968, 452/3/3 (HP ARBARK).

15 Letter from Barry Commoner to Hans Palmstierna, 15 January 1968, 452/3/3 (HP ARBARK); Letter from Hans Palmstierna to Barry Commoner, 29 January 1968, 452/3/3 (HP ARBARK).

16 Letter from Jacques de Reus to Hans Palmstierna, 17 January 1968, 452/3/3 (HP ARBARK); Letter from Petter Åkerman to Hans Palmstierna, 
Some politicians approached Palmstierna directly in order to describe how they had begun to work with environmental issues. The Social Democrat Samuel Strandberg sent over a statement he had made to Stockholm City Council, and Axel Jansson, a member of the Left Party [in those days 'the Left Party - the Communists'], enclosed a motion his party had raised in the Riksdag. ${ }^{17}$ Palmstierna also accepted a request from the Left Party's youth association to come to Café Marx in Stockholm and give a lecture. ${ }^{18}$ But the political left was not the only actor that courted him. In late January, he had lunch at Handelsbanken's head office with its chairman of the board, Tore Browaldh (Handelsbanken was and remains one of the largest commercial banks in Sweden). The meeting was followed by amiable thank-you letters and a continued exchange of ideas. Browaldh was delighted to have met Palmstierna in person, the man whose book had functioned as 'something of an alarm clock' for his 'entire family'. ${ }^{19}$

Another Handelsbanken correspondent was lawyer Gustaf Delin. He chaired Sigtuna Town Council and represented a small group of individuals with a commitment to municipal politics. They appealed to Palmstierna for moral support and with a view to investigating whether Sigtuna could be made an 'experimental site for good environmental protection'. The group found it 'highly unsatisfactory to have to deal with environmental problems only when they become urgent'. Consequently, they wanted a system to be developed that would enable long-term planning of the municipality's activities. Delin told Palmstierna the group had recently submitted a motion to upgrade the local waste-water treatment plant. Might Associate Professor Palmstierna possibly have the time and interest to meet over lunch ${ }^{20}$

24 January 1968, 452/1/4 (HP ARBARK); Letter from Hans Palmstierna to Jacques de Reus, 23 January 1968, 452/3/3 (HP ARBARK).

17 Letter from Samuel Strandberg to Hans Palmstierna, 9 January 1968, 452/3/3 (HP ARBARK); Letter from Axel Hansson to Hans Palmstierna, 22 January 1968, 452/3/3 (HP ARBARK).

18 Letter from the Left Party's youth association to Hans Palmstierna, 24 January 1968, 452/3/3 (HP ARBARK).

19 Letter from Hans Palmstierna to Tore Browaldh, 29 January 1968, 452/3/3 (HP ARBARK); Letter from Tore Browaldh to Hans Palmstierna, 2 February 1968, 452/3/3 (HP ARBARK).

20 Letter from Gustaf Delin to Hans Palmstierna, 18 February 1968, 452/3/3 (HP ARBARK). 
A more informal group which made its voice heard in early 1968 consisted of Bo and Birgitta Wrenfelt and some friends of theirs. They had met in the couple's home for an evening of discussion about problems and environmental destruction in developing countries. The group members felt that the established political parties' handling of environmental issues was 'completely unsatisfactory'. They particularly criticized government minister Krister Wickman's assertion in the television programme Monitor about the electorate's lack of interest and commitment. 'How do the politicians know this?' they asked. 'As far as we know, no political party has presented its intentions regarding environmental issues before any election.' The group stressed that 'the electorate's behaviour' could certainly be observed - for example, from the fact that both the price of and demand for lake fish in the Stockholm area had fallen by 50 per cent in a short period of time. This could not be due to anything other than information and growing commitment. The group added that there was 'a large group of people who are seriously concerned about their own and their children's future'. They therefore wrote to Radio Sweden to request that it organize a televised debate without a set time limit, a debate which was to take place as soon as possible and include all political parties as well as leading environmental experts. Signed by seventeen people, the letter was sent to Hans Palmstierna, Radio Sweden, the five political party offices, Olof Lagercrantz at Dagens Nybeter, and three of the researchers behind Människans villkor. ${ }^{21}$

The many initiatives taken at the beginning of 1968 show that environmental issues had a broad public appeal. Within three months, Plundring, svält, förgiftning had sold 16,000 copies and been published in a third edition. ${ }^{22}$ The letters also reveal that Hans Palmstierna was in demand. People wanted to meet, talk to, and listen to him as well as obtain his signature and support. Several editors contacted him too, asking him to write for their periodicals. While generally accommodating to editors, he largely recycled his own texts. Brief and lightly reworked excerpts from Plundring, svält, förgiftning appeared in many different contexts in 1968 . He did continue to publish newly written texts, however, mainly in Dagens Nyheter; but what particularly characterized this phase was that he began to employ new media

21 Written communication from Bo and Birgitta Wrenfeldt, February 1968, 452/3/3 (HP ARBARK).

22 Advertisement for Plundring, svält, förgiftning, DN, 31 January 1968. 
and channels. Recordings for Skol-TV [school television] and the collaboration with Folksam were of particular importance. ${ }^{23}$

\section{'A front against environmental destruction'}

On 30 January 1968, Folksam organized a start-up conference in Stockholm to launch the above-mentioned 'front against environmental destruction' campaign. Valfrid Paulsson and Hans Palmstierna each gave an introductory speech. The main focus of the conference was to present the design of the campaign. Folksam announced that it was chiefly aimed at young people in Sweden and was intended to function as a three-stage rocket. First, youth associations and school classes would be informed by watching a still film and working with study materials. In order 'to achieve the greatest possible activity and the best possible results', the material contained competitive elements. The young participants were encouraged to investigate their local environmental situation for themselves. They would then present the results in a creative format, such as a wall poster, an essay, or a photo montage. These could be submitted to Folksam to be judged by a jury which included Paulsson and Palmstierna. The best entries would be rewarded, the prize money totalling SEK 20,000. ${ }^{24}$

The goal of the Folksam campaign was to create an informed and impatient body of opinion that could drive developments forward. The offensive was to culminate in the spring of 1969, with public hearings held throughout Sweden. At these, educated and committed young people were to challenge municipal politicians, Riksdag members, business leaders, and nature conservationists. Folksam described the events as 'a kind of committee hearing'. ${ }^{25}$ Barbro Soller compared them to the fierce interrogations that US presidents sometimes had to face. ${ }^{26}$

The 'front against environmental destruction' had strong support within Folksam. Throughout 1968, and until the summer of 1969,

23 Letter from Hans Palmstierna to Sören Gunnarsson, 14 January 1968, 452/3/3 (HP ARBARK); Bria Ekwall, 'Lärare matematikutbildas: Jättekurs i radio och TV', DN, 16 January 1968.

24 Barbro Soller, 'Bister kampanjupptakt: Avfallsproblem olösta när industri startar', DN, 31 January 1968; Anon., 'Front mot miljöförstöringen i ny ungdomsgiv', pp. 4-5.

25 Anon., 'Front mot miljöförstöringen i ny ungdomsgiv', p. 5.

26 Barbro Soller, 'Bister kampanjupptakt'. 
the campaign and related activities received a lot of space in the insurance company's magazine. After the launch on 30 January, it was documented that 'practically all newspapers of any importance' in Sweden had reported on the youth campaign's design and aims. The same was true of radio and television. ${ }^{27}$ The driving force in Folksam was the secretary of its youth council, Anders Ericsson. In the spring of 1968, he travelled throughout Sweden to encourage associations and schools to participate in the campaign. In total, about thirty information and networking conferences were held - events at which Ericsson, and sometimes also Palmstierna, described the format and content in some detail. Ericsson believed that the response was greater than any previous youth programme had elicited. Throughout the country, he said, there was 'a deep commitment to and responsibility for environmental issues', and he described the situation prior to the campaign's autumn launch as 'the best imaginable'. ${ }^{28}$

Palmstierna's correspondence from this time contains only a few letters from primary- and upper-secondary-school pupils. ${ }^{29}$ In contrast, many university students did write to him. One of them was Lars Emmelin. He had studied zoology, zoophysiology, and genetics in Lund and worked as an assistant at the Department of Zoology. Unfortunately, he had not been able to attend Palmstierna's lecture in Lund, which was why he was writing a letter. Had the assistant professor indeed called for 'volunteers for some kind of action'? Was he referring to Folksam's campaign? Emmelin offered to sign up without reservation for whatever it was, listing his qualifications, in order to 'facilitate the assessment of whether I can be used for anything'. In addition to his studies in natural science, he cited his many activities within the student union, from which he had gained committee experience. He particularly wanted to do 'teaching and some kind of journalistic activity'. ${ }^{30}$

Palmstierna quickly replied that he would forward Emmelin's letter to Anders Ericsson at Folksam. He added that the popular

27 Anon., 'Press och miljö', Folksam, 1 (1968), p. 28.

28 Anon., 'Ungdomsorganisationer och skolor "heltända” på miljövård', Folksam, 3 (1968), p. 39; Anon., 'Front mot miljöförstöringen', Folksam, 3 (1968), pp. 53-55.

29 Letter from Larseric Stoltz to Hans Palmstierna, 3 April 1968, 452/3/3 (HP ARBARK); Letter from Thomas Hedner to Hans Palmstierna, 27 April 1968, 452/3/3 (HP ARBARK).

30 Letter from Lars Emmelin to Hans Palmstierna, 5 March 1968, 452/3/3 (HP ARBARK). 
movements and their various educational institutions would show a slide presentation plus a short speech by himself to the young people who were active in associations. The hope was to engage a greater number of interested younger people, who would then be given access to more study materials whereupon they would start getting ready for public hearings. Palmstierna stressed that, during both the study activities and the hearings, it was important that there were "knowledgeable people in the background, so that the young people would not be clobbered with the usual dodges and tricks'. He hoped that Emmelin might consider taking on such a role, adding that Emmelin was welcome to visit him at the National Environment Protection Board. ${ }^{31}$

Whether Lars Emmelin did become involved in 'A front against environmental destruction' is unclear. A subsequent letter makes it clear that Folksam did not contact him, at least not immediately. However, the friendly relationship with Palmstierna had been established. Before Palmstierna paid a new visit to Lund in May 1968, Emmelin wondered if he and his fiancée might offer 'lunch, dinner, supper' or the like. He said that he had the run of his parents' house and offered Palmstierna 'accommodation and a work space', a friendly welcome and breakfast. ${ }^{32}$ There is no doubt that Emmelin was keen to strengthen the contact and initiate new shared ventures. In this he became successful. In the autumn of 1968, together with some other students and part-time instructors - and with Palmstierna's direct support - he organized Sweden's first course in environmental protection.

\section{Key groups and student involvement}

Hans Palmstierna and Folksam regarded young people as drivers of long-term social change. Many young people shared this view. In Palmstierna's correspondence, this mindset is manifested in a variety of ways. One example is when Wolter Arnberg, editor of Fältbiologen [The field biologist], contacted him with a request for an article in January 1968. Arnberg stressed that the magazine's young readers were very knowledgeable and could be expected to be 'tomorrow's opinion-makers on the environmental

31 Letter from Hans Palmstierna to Lars Emmelin, 7 March 1968, 452/3/3 (HP ARBARK).

32 Letter from Lars Emmelin to Hans Palmstierna, 1 May 1968, 452/3/3 (HP ARBARK). 
front'. ${ }^{33}$ Palmstierna was not hard to persuade and soon submitted a script.

Håkan Sundberg, a student at Chalmers University of Technology in Gothenburg, expressed himself even more precisely. He said that 'Chalmerists' were a conservative group of students 'who, ridiculously enough, gain access to strategic positions in the expansion society merely by virtue of their education'. It was therefore crucial that they be 'given a jolt'. Sundberg wondered whether Palmstierna might consider writing an article on the theme of 'the engineer's responsibility' for the student magazine, Tofsen. He also asked if Palmstierna could come to Gothenburg in March to participate in a podium debate. ${ }^{34}$ Palmstierna's reply took almost a month, for which he apologized, citing his new position at the National Environment Protection Board. For the same reason, too, he did not have the opportunity to 'prod your conservative lobsters so early this year'. However, he was anxious to come and speak to the Chalmerists and hence asked Sundberg to contact him again at some point. Palmstierna also encouraged Sundberg to take an active part in Folksam's campaign and passed on his contact details to Anders Ericsson. ${ }^{35}$ A month or so later, Palmstierna submitted the article 'Teknik i livets tjänst' [Technology in the service of life]. ${ }^{36}$

In February, Palmstierna was also contacted by Lennart Lindqvist, a student at the Agricultural College of Sweden in Uppsala. A representative of the student association JUF (Jordbrukare Ungdomens Förbund [Agricultural Youth Association]), Lindqvist wondered if Palmstierna could come and speak to them one evening in April. Lindqvist stressed that all the students at the college came into contact with 'the problems connected with the destruction of the environment and of natural resources' and that these issues directly affected their 'future professional practice'. Consequently, the students were very keen to '[have] the problems clarified as comprehensively

33 Letter from Wolter Arnberg to Hans Palmstierna, 18 January 1968, 452/3/3 (HP ARBARK).

34 Letter from Håkan Sundberg to Hans Palmstierna, 2 February 1968, 452/3/3 (HP ARBARK).

35 Letter from Hans Palmstierna to Håkan Sundberg, 25 February 1968, 452/3/3 (HP ARBARK).

36 Hans Palmstierna, 'Teknik i livets tjänst', Tofsen 4 (1968), 10-14. 
as possible'. ${ }^{37}$ Palmstierna accepted the invitation, saying that he was grateful for the opportunity to reach out to this 'key group'. ${ }^{38}$

The most ambitious student initiative in the spring of 1968 , however, occurred in Lund. A high-profile lecture series was to be held there with a focus on world poverty, overpopulation, and the difficult situation of developing countries. The keynote speaker was John Kenneth Galbraith, the world-renowned public debater and professor of economics at Harvard. ${ }^{39}$ In addition, the Lund students managed to invite Raúl Prebisch, the secretary-general of the United Nations Conference on Trade and Development (UNCTAD). They also booked in prominent Swedish figures, such as Professors Gunnar Myrdal and Georg Borgström, plus the influential social democratic theorist Gunnar Adler-Karlsson. The students were eager for Hans Palmstierna to participate as well. They stressed that the event was 'completely apolitical', with the exception of a planned public opinion meeting on about 20 March which aimed to put pressure on the Swedish government. The students intended to demand that Sweden 'immediately meet the developing countries' demands at UNCTAD II'. The organizers expected that Palmstierna would 'attract a full house (1,000 people)', which was twice as many as at a regular 'student evening, ${ }^{40}$ Thanks to Palmstierna's participation, the Lund campaign came to encompass environmental issues; but they were hardly a primary consideration.

Even so, environmental involvement in the Scanian student city was growing. By May, Palmstierna was already there again. At that time, the law students' association, Juridiska föreningen, held a debate in the Academic Society's large auditorium on the theme of 'Environmental destruction - The price of prosperity?' The students underlined that environmental destruction was 'a most acute problem' of 'crucial importance to the existence of future generations'. What

37 Letter from Lennart Lindqvist to Hans Palmstierna, 18 February 1968, 452/3/3 (HP ARBARK).

38 Letter from Hans Palmstierna to Lennart Lindqvist, 25 February 1968, 452/3/3 (HP ARBARK).

39 Rolf Lindblad, 'Galbraith i Lund', DN, 17 March 1968. For a study of Galbraith's significance in Scandinavian politics and social debate, see Björn Lundberg, 'The Galbraithian Moment: Affluence and Critique of Growth in Scandinavia, 1958-1972', in Östling, Olsen, and Larsson Heidenblad (eds), Histories of Knowledge in Postwar Scandinavia, pp. 93-110.

40 Letter from Sven Herner to Hans Palmstierna, January 1968, 452/3/3 (HP ARBARK); Letter from Sven Herner to Hans Palmstierna, 26 February 1968, 452/3/3 (HP ARBARK). 
could be done to stop it? What role did legislation play? In addition to Palmstierna, the other participants included Christer Leijonhufvud of the Swedish National Federation of Industry and a senior judge, Ingemar Ulveson. ${ }^{41}$

The following week, Palmstierna travelled to Gothenburg to officially open the provocative exhibition $\ddot{A} n$ sen $d a ̊$ ? [So what?]. It was the brainchild of a group of architecture students at Chalmers, including the previously mentioned Håkan Sundberg. The exhibition was built in room-size sections of corrugated cardboard. Each room confronted the visitor with texts and pictures portraying humanity's living conditions. One section was about the Earth's limited resources. Another dealt with the rich world's luxury consumption and space travel. A third highlighted developing countries' poverty and lack of contraception. In the background, a counting device ticked softly at three beats per second. Göteborgs-Posten's reporter informed readers that in just six hours the counter had reached 66,557 . That was how many people had been born into the world since the opening of the exhibition. ${ }^{42}$

$\ddot{A} n$ sen $d a$ ? made a powerful impact. It was exhibited for nine days in Gothenburg, whereupon it set out on a national tour. In June it arrived in Stockholm, where it was opened by the then-minister for education, Olof Palme. Dagens Nyheter described it as 'an unusually intelligent way' of uttering a protest. ${ }^{43}$ Svenska Dagbladet took up a similar position, stressing that the exhibition did not restrict itself to addressing the problems of developing countries' problems and global starvation; '[e]nvironmental destruction in all its fantastic forms is illuminated effectively and powerfully'. For example, the exhibition showed that two metro lines transported as many people as sixty car lanes. 'Which alternative is the most economical, the most socially beneficial?' asked the writer. 'Which alternative makes the greatest contribution to the stemming of environmental destruction? ${ }^{44}$

41 Letter from Gunilla Hasselmo to Hans Palmstierna, 30 April 1968, plus the enclosed cutting from the student newspaper luset, 452/3/3 (HP ARBARK).

42 C. A., 'Medan vi väntar på världskatastrofen: Se på debattutställningen "Än sen då?"', GP, 15 May 1968.

43 Viveka Vogel, 'Skärpt sätt att protestera', DN, 13 June 1968.

44 Mari, 'Proteinrikt fiskmjöl blir kattmat i USA', SvD, 13 June 1968. 


\section{Schools and the environment}

Hans Palmstierna was keen to spread his message in primary and upper secondary schools. Through Folksam's campaign plus recordings of environmental programmes for Skol-TV, he sought to involve teachers and pupils. By the spring term of 1968, however, he still had not produced any educational material. Teachers who wanted to introduce environmental issues into their tuition therefore had to strike out on their own. Traces of their initiatives may be found in correspondence and press clippings.

At the beginning of March an upper-secondary-school teacher named Sven-Ake Kroon wrote to Palmstierna, saying that he had read Plundring, svält, förgiftning several times and that the book had made him 'very frightened'. Kroon taught the subject of energy to future graduates of the school's engineering programme. He explained that the subject was closely tied to environmental issues, but that these aspects were not included in the curriculum. 'I am totally convinced that this state of affairs has to change', he said, adding that he did not intend to wait for others to act. Fortbildningsinstitutet in Stockholm [a further-education institution, later incorporated into the Stockholm Institute of Education, now part of Stockholm University - translator's note] had commissioned him to teach a further-education course for upper-secondary-school teachers on the subject of energy. The course would take place in the ski resort of Åre in August, and Kroon planned to focus on environmental issues. He wondered if Palmstierna could give a guest lecture, which Kroon hoped would act as a wake-up call for the energy teachers. ${ }^{45}$

Palmstierna immediately answered that he was interested, but that there was one drawback: recordings for Skol-TV were scheduled for the late summer. 'If this does not conflict with your course, naturally I will come.' He added that it was appalling that the upper-secondary-school engineers' curriculum did not include biology, let alone ecology. 'These, after all, are the people who must subsequently make decisions that are of the utmost importance for our environment, decisions that are now being made without any knowledge base.' He hoped Kroon and his colleagues would point out these shortcomings via their trade union. ${ }^{46}$

45 Letter from Sven-Åke Kroon to Hans Palmstierna, 6 March 1968, 452/3/3 (HP ARBARK).

46 Letter from Hans Palmstierna to Sven-Åke Kroon, 7 March 1968, 452/3/3 (HP ARBARK). 
Another initiative was taken in the spring of 1968 by pupils at the technological upper-secondary school in Luleå. In collaboration with the local healthcare agency, they planned a joint action 'to clean up the city of Lulea and its surroundings'. To be launched in mid-May, the campaign would urge the general public 'to take to the streets, one and all'. The next day, the technology pupils would 'add the finishing touches and clean up the areas that had been missed'. In addition to the cleaning initiative, the 'Clean Luleå' campaign included prize competitions, guest lectures, and a podium debate. The upper-secondary-school pupils were eager for Palmstierna to attend, but he was unable to do so. ${ }^{47} \mathrm{~A}$ few days later, he also declined a request from a senior upper-secondary-school teacher, Gunnar Ander, to come and speak in front of an 'informal group of academics' in Bromma. ${ }^{48}$

The biggest school venture in the spring of 1968 occurred at a primary school in Gothenburg. In the second half of April, the school intensified its environmental instruction. The aim was 'to awaken pupils' realization of the importance of environmental and nature conservation measures for tomorrow's society'. The core instruction was provided in the form of two exhibitions - one designed by the school and the other by the Society for the Promotion of Ski Sport and Open Air Life in Sweden. The arrangement began on 16 April with a lecture by the county's nature conservation officer and ended on 29 April with a lecture by Hans Palmstierna. A podium debate followed, including Palmstierna, local politicians, and officials with relevant responsibilities. To 'stimulate the pupils' own involvement', essay, drawing and photo competitions were organized on the theme of the environment. ${ }^{49}$

On his own initiative, a teacher named Lennart Rådström prepared a mimeographed outline entitled 'Humans in the biological environment'. Five pages long, it began with a quotation from Plundring, svält, förgiftning. Rådström emphasized that rapid technological development and explosive population growth had disrupted nature's state of equilibrium. Humanity was now on the brink of destroying its own habitat. For that reason, active environmental protection

47 Letter from Larseric Stoltz to Hans Palmstierna, 3 April 1968, 452/3/3 (HP ARBARK).

48 Letter from Gunnar Ander to Hans Palmstierna, 8 April 1968, 452/3/3 (HP ARBARK).

49 Anon., 'Miljöförstöringsproblem nytt ämne i Partilleskola', GP, 10 April 1968. 
appeared to be a basic prerequisite for humanity's 'continued existence on Earth'. The pupils were tasked with 'drawing some simple food chains' plus a picture of how plants and fish in an aquarium were co-dependent. ${ }^{50}$

Porthälla School's local initiative was matched by earnest discussions at the national level. On 30 May, the National Board of Education held a conference about teaching environmental conservation. Barbro Soller reported that the conference clearly showed that 'the school system's current effort is inadequate, to say the least'. She was particularly concerned that the upper-secondary-school pupils in the engineering and economics programmes had no opportunity to receive instruction in the subject. How, then, would they be able to 'find the practical solutions for tomorrow's environmental protection'? The Board's consultant on school issues, Stig Fred, emphasized that the curriculum had been drawn up the early 1960s and that time had 'partially passed it by'. Sven-Anders Björsne, who worked at the teacher-training college in Malmö, felt that the National Board of Education should intervene with full force as soon as possible. The urgent problem called for special treatment in the same way as had previously happened with regard to sex education. $^{51}$

There was widespread agreement at the conference that the school curriculum neglected environmental issues. The National Board of Education announced that it had set up an expert group who had been told to ensure that the issues were given more space in the next curriculum. It was also stated at the conference that school pupils themselves had begun to react. Lennart Hultgren, a teacher and member of the Biology Teachers' Association, said that one of his pupils had expressed it as follows: 'What exactly are you giving us young people with your best-welfare attitude? Well, bad air, contaminated water, toxic food - a real shit society!' The comment was quoted in both Svenska Dagbladet and Dagens Nybeter. ${ }^{52}$

50 Lennart Rådström, Människan i den biologiska miljön, 1968, 452/2/1 (HP ARBARK).

51 Barbro Soller, 'Läroplanen lider av fläcktyfus. Torftig miljövårdsundervisning', DN, 31 May 1968.

52 Ibid.; Monique, 'Läroplan och lärarutbildning anpassas till miljövårdsfostran', SvD, 31 May 1968. 


\section{The various forms of environmental involvement}

The adult world could hardly be said to be indifferent to the environmental problems, though. Many people had woken up by 1968. This trend may be illustrated with figures from the National Library of Sweden's digitalized archive of the Swedish daily press. For example, we find 120 hits for the word 'miljövård' [environmental protection] for the year 1967 and 891 hits for the year $1968 .^{53}$ Research done at that time confirmed this trend. In the summer of 1968, professor of pedagogy Åke W. Edfeldt conducted telephone interviews which showed that the majority of the general public had good knowledge about mercury poisoning in nature and considered the media reporting on the issues to be reasonable. It was also possible to prove that fish consumption had fallen in connection with the publication of various alarming reports. ${ }^{54}$ At the Riksdag level, twenty-one motions were presented that year on the topic of protecting nature and the environment, to be compared with a mere seven the year before. ${ }^{55}$

However, these types of quantitative measures are blunt tools for investigating the breakthrough of environmental issues in Sweden. Both linguistic usage and the understanding of the environmental problems were in a state of rapid flux. This makes it difficult to know what to compare with what in order to map lines of development over time. Concepts such as 'nature conservation' and 'environmental protection' were used interchangeably, and they could - but did not have to - refer to the same phenomenon. A specific term might have certain connotations in 1966 and quite different ones in 1968. For example, the dangers of mercurycontaminated watercourses and acid rain were sometimes linked to a global set of problems and sometimes not. Given these reservations, though, the above-mentioned quantitative readings of the national pulse do indicate that there was a degree of intensification in 1968. This is also consistent with the ways in which the historical actors themselves, such as Birgitta Odén and Sören Gunnarsson, commented on the phenomenon. The change is palpable in Hans Palmstierna's correspondence, too. By scrutinizing that

53 Search on the word 'miljövård' at www.tidningar.kb.se (accessed 29 May 2020).

54 Åke W. Edfeldt, Kvicksilvergäddan (Stockholm: Tiden, 1969).

55 Record of proceedings in the Riksdag plus appendices 1961-1970. Vol. 3, Index, L-Ö. 
development, we can move close to the historical process of change in a qualitative way.

One of the people who began to take an interest in environmental issues in the spring of 1968 was Eric Bergh in Gothenburg. He introduced himself to Hans Palmstierna as 'one of the many Gothenburgers who do not usually demonstrate or otherwise make our voice heard'. Bergh expressed his 'heartfelt thanks' to Palmstierna for the latter's great efforts in the field of environmental protection and described how he and some friends had compiled and circulated a petition. By such means, the group sought 'to express directly what those of us at the popular level want in these matters'. They had hence been careful to ensure that only people 'who had read it and had taken a firm personal stand' signed the petition. The group had not allowed any representatives of associations or organizations to sign collectively. In just a few days, 700 signatures had been collected. The group's petition had been noticed and cited in the press, and it had begun to be circulated within the city administration. Bergh enclosed a copy of the petition in his letter to Palmstierna, so that the latter could gain insight into what was happening in Gothenburg prior to his upcoming visit there.

The first sentence of the petition emphasizes that it was precisely the adult world that was raising its voice. 'We, families in Gothenburg, protest against our children's having to grow up and develop in an increasingly poisoned environment, created by our senseless scurrying after material standards and our mentality of earnings and profit.' The wording of that protest contained echoes of Hans Palmstierna's own rhetoric. The signatories of the petition demanded that measures be implemented immediately. They wanted to see a ban on leaded petrol, on the mass emission of biocides, and on the construction of new multistorey car parks in the city centre. They called for mandatory exhaust filters on cars and buses, better purification systems in factories, and the construction of new sewage-treatment plants. They also wanted to see more effective measures against 'alcohol and drug abuse, a ban on advertising for alcohol and tobacco, [and] strong measures for the cure and rehabilitation of alcoholics'. The detailed passage about abuse may seem to be a poor fit in the context. After all, the appeal's focus was on fresh air, clean water, and a healthy living environment. ${ }^{56}$ But it indicates a general tendency

56 Letter from Eric Bergh to Hans Palmstierna, 15 May 1968, 452/3/3 (HP ARBARK). 
in the material. The commitment to the environment was not an isolated phenomenon; it was linked to other issues that people cared about. For some, those issues were development at home and abroad, overpopulation, and world peace; for others, they were experiences of nature, historical research, and alcohol abuse.

People with artistic ambitions were able to manifest their environmental commitment via forms of aesthetic expression. One such individual was the troubadour Anders Fugelstad. In June 1968, he sent some printed song lyrics to Palmstierna. Fugelstad stressed that he was happy for them to be used and that he himself would be available for suitable assignments. His lyrics contained lines such as 'the population is increasing every minute / the love of raw materials must end' and 'I suppose our prosperity must cost us our well-being / and so far I still have the strength to cough'. He sang about horses that had died of carbon-monoxide poisoning and mountain streams that had become polluted rivers. ${ }^{57}$ The same approach was adopted by the established poet Stig Carlsson, who dedicated the poem 'Om vissa förutsättningar' [About certain conditions] to Hans Palmstierna. The poem levelled harsh criticism at space travel and global injustices. Carlsson argued that humanity should focus its attention on the face of the Earth rather than on the far side of the moon. The most important thing was good harvests and that people could eat their fill. 'And this strikes me', he concluded, 'as an almost childish opinion. ${ }^{58}$

The summer of 1968 also saw examples of organized student involvement. The most ambitious case was a two-week seminar event at the Konstfack School of the Applied Arts in Stockholm [now Konstfack University of Arts, Crafts and Design] on the theme 'Humanity - the Environment'. The guest lecturers included CarlGöran Hedén and Tor Ragnar Gerholm. The students devoted themselves to workshops and group projects. Prior to the event, they edited a special issue of the magazine called Form, which featured the responsibility of design students for the development of society. ${ }^{59}$ Palmstierna was invited to speak, but could not attend. However, in a radio talk entitled 'De klarsyntas revolt' [The rebellion of the clearsighted ones], he expressed his great support for students

57 Letter from Anders Fugelstad to Hans Palmstierna, 14 June 1968, 452/3/3 (HP ARBARK).

58 Stig Carlsson, Förbifarter (Stockholm: Norstedts, 1968), pp. 38-39.

59 Letter from Eva Lamby to Hans Palmstierna, June 1968; Rebecka Tarschys, 'Konstfackare vill ta ansvar', DN, 22 July 1968. 
around the world who turned against established institutions in society in the late spring of 1968 . 'The young people are rebelling because they want to continue living', he pointed out. The students were rightly attacking those who were steering the world 'straight into a coming hell'. It was not defensible to send in 'vigilantes and riot police' against this uprising. On the contrary, society should invite the young generation to 'plan the society in which they will be living'. That was a prerequisite for building a better world and ensuring humanity's survival. ${ }^{60}$

The environmental issues intersected with the lives of older people as well. One of them was Valfrid Irskogen from Malmö. He had been told by a relative that the mining company Boliden 'cast arsenic into cement blocks' and then dumped them in the Gulf of Bothnia. This behaviour, if true, frightened him. In his childhood in the 1890s, many people had used 'arsenic dissolved in water on a plate as fly poison'. For that reason, he contacted Palmstierna to inform him of his suspicions. ${ }^{61}$ Another elderly man from Skåne who wrote to Palmstierna was Zenon P. Westrup. A retired diplomat and former chairman of the local nature-conservation association in Malmö, Westrup introduced himself as 'an old labourer in the vineyard' who had great interest in and sympathy for 'your teachings in the context of nature conservation'. However, Westrup was disappointed that Palmstierna was mixing politics into the issues. That was, he wrote, 'the most disastrous thing that could happen to our common interests in this field'. He especially objected to Palmstierna pinning his hopes on the Social Democratic movement. To Westrup, such a view was almost grotesque. As a 'reasonably good right-winger' he had for decades 'fought, written, quarrelled and become enemies with people' by pushing nature-conservation issues at the local level. His opponents had most often been Social Democrats. Still, Westrup did not want to single out that party as being worse than others. Instead, he argued that 'the entire Swedish people' had constructed 'the same simple and barbaric scale of values with regard to priorities between material benefits and environmental values' over a long period of time. $^{62}$

60 Hans Palmstierna, 'De klarsyntas revolt', in Angeläget idag (Stockholm: Sveriges Radio, 1968), pp. 128-129.

61 Letter from Valfrid Irskogen to Hans Palmstierna, 7 July 1968, 452/3/3 (HP ARBARK).

62 Letter from Zenon P. Westrup to Hans Palmstierna, 18 July 1968, 452/3/3 (HP ARBARK). 
Palmstierna responded by sending Plundring, svält, förgiftning to Westrup. It was received as 'an exquisite and disarming expression of amiability'. Westrup wrote that he was ashamed of not having read the book when it had first come out, adding that it was Birgitta Odén who had drawn his attention to Palmstierna's activities. However, he still insisted that the politicization of nature-conservation issues posed a danger to their shared interests. Socialist politicians, just like progress-seeking business leaders, were easily seized 'by the same idolization of technology' and by economistic perspectives. A look at 'the former and the current head' of the state-owned energy company Vattenfall was proof enough, he said. ${ }^{63}$

Westrup's two letters to Palmstierna are of general interest. They provide insights into the conflict-filled encounter between older nature-conservation interests and the emerging policy of environmental protection. The former had roots in the late nineteenth century when (among other things) the Swedish Society for Nature Conservation was formed. Its focus lay on protecting the wilderness from industrial expansion, for example by founding national parks. Nature conservation had traditionally had a bourgeois flavour with close ties to the university world, ${ }^{64}$ and this background is obvious in Westrup's letters. His path to Palmstierna did not go via the press, the book market, or popular movements. It went via Professor Birgitta Odén, whom he had contacted after she had sent him the programme for 'some kind of "study group" for environmental issues'. ${ }^{65}$

\section{Outside Sweden's borders}

The intertwined breakthroughs for environmental issues and for Hans Palmstierna personally were a Swedish phenomenon. In most other countries, a commitment to the environment was still a marginal phenomenon in 1967 and 1968. The major exception was the United States, where Barry Commoner and Paul Ehrlich attracted

63 Letter from Zenon P. Westrup to Hans Palmstierna, 1 August 1968, 452/3/3 (HP ARBARK).

64 Désirée Haraldsson, Skydda vår natur!: Svenska naturskyddsföreningens framväxt och tidiga utveckling (Lund: Lund University Press, 1987); Jonas Anshelm, Det vilda, det vackra och det ekologiskt hällbara: Om opinionsbildningen i Svenska Naturskyddsföreningens tidskrift Sveriges natur 1943-2002 (Umeå: Umeå universitet, 2004).

65 Letter from Zenon P. Westrup to Hans Palmstierna, 18 July 1968, 452/3/3 (HP ARBARK). 
considerable attention in the public debate during those two years. ${ }^{66}$ However, in contrast to Palmstierna, they were far from the centre of political power. In a letter to Olof Palme, Palmstierna said that his scientific friends in the United States 'envy us our opportunities to reach out to people with a message via the popular movements'. Besides, he added, the American mass media were sitting on the lap of industrial and commercial interests. As a result, they could not 'spread knowledge about such matters as the destruction of nature and resources in the same way as we [can] here in Sweden' ${ }^{67}$

Against this background, it is hardly surprising that the lion's share of Palmstierna's surviving correspondence is in Swedish. However, some threads do lead outwards. In January 1968 he was contacted by the Dutch lawyer Jacques de Reus, who had previously lived in Stockholm. De Reus had become aware of Palmstierna through Dagens Nybeter's series of articles in the 'environment of the future'. The Dutchman said that environmental problems 'apply even more' to a densely populated, industrialized country such as the Netherlands. He therefore wondered whether Palmstierna might be interested in a translation into Dutch. He himself would happily 'act as a middleman to persuade a publisher of the book's importance' ${ }^{68}$ Palmstierna replied enthusiastically - in Dutch. He and his sister had spent part of their childhood in the Netherlands during the Second World War, and de Reus's letter became the start of a lengthy correspondence. ${ }^{69}$

Still, most of non-Swedish interest in Palmstierna's operations came from the neighbouring Nordic countries, where many people were following the Swedish developments. One of them was the Finnish-Swedish student Richard Ahlqvist. He was studying architecture at the Helsinki University of Technology and planned to devote his graduation-essay project to waste management. For him,

66 Adam Rome, “'Give Earth a Chance”: The Environmental Movement and the Sixties', Journal of American History 90.2 (2003); Egan, Barry Commoner and the Science of Survival; Robertson, The Malthusian Moment; Rome, The Genius of Earth Day.

67 Letter from Hans Palmstierna to Olof Palme, 27 April 1968, 452/3/3 (HP ARBARK).

68 Letter from Jacques de Reus to Hans Palmstierna, 17 January 1968, 452/3/3 (HP ARBARK).

69 Letter from Hans Palmstierna to Jacques de Reus, 23 January 1968, 452/3/3 (HP ARBARK). For his childhood, see Gunilla Palmstierna-Weiss, Minnets spelplats (Stockholm: Bonnier, 2013). 
the whole topic had 'grown much larger than just an interest'. He explained that his entry point had been Palmstierna's article in Dagens Nyheter entitled 'Förskingringen kan hejdas' [The embezzlement can be stopped] (21 March 1967). Consequently, he wanted to meet Palmstierna to discuss his ideas and said he could come to Stockholm at any time. ${ }^{70}$

The reply has not been preserved, but from Ahlqvist's next letter it is clear that Palmstierna had suggested meeting in Helsinki on 6 June. Ahlqvist could not make that date, though. He added, in a tone of disappointment, that his planned degree project had run into opposition. The Department of Architecture's faculty felt it was too extensive. Besides, they thought that Ahlqvist lacked the proper qualifications for the job and suggested that he engage in 'something more artistic'. Ahlqvist had protested in vain, and his plans looked like remaining at the idea stage. He nevertheless thanked Palmstierna for the latter's kind letters and stressed that environmental problems were still 'unresearched areas in Finland'. He therefore hoped he could 'do his own small part to add to a growing awareness of and opposition to the mismanagement'. He was also pleased to see that Palmstierna 'had been contacted about a major summer seminar at Sveaborg in July'. Perhaps they might get together there? ${ }^{71}$

The impression that Sweden was at the forefront of environmental protection was also expressed by a diplomat working in Oslo, Ivar Öhman. He said that Norway had not yet 'arrived at our "tough" views and demands'. He was contacting Palmstierna because he had seen the exhibition $\ddot{A} n$ sen då? during a visit to Stockholm. He had found it 'damned disturbing and important' and therefore wanted to bring it to Oslo, where he felt it could 'do a lot of good'. He envisioned lectures, podium debates, and film screenings in conjunction with the exhibition. 'Of course' the event would 'target a young audience'. Might Palmstierna have the contact details of the students behind the exhibition? ${ }^{72}$

Another Swede living abroad who wanted to spread Palmstierna's message was H. William-Olsson. He lived in London, where he was the honorary secretary of the Anglo-Swedish Society. The Society

70 Letter from Richard Ahlqvist to Hans Palmstierna, 4 May 1968, 452/3/3 (HP ARBARK).

71 Letter from Richard Ahlqvist to Hans Palmstierna, 30 May 1968, 452/3/3 (HP ARBARK).

72 Letter from Ivar Öhman to Hans Palmstierna, 3 July 1968, 452/3/3 (HP ARBARK). 
sought 'to act as a catalyst in the Swedish/English exchange of ideas'. William-Olsson wondered if Palmstierna was planning to visit London in the autumn. Unfortunately, the Society did not have the funds to pay for the trip, but its members were eager for him to come and speak to them. William-Olsson explained that they had good contacts with the press and the BBC, and that the lecture could therefore be a springboard for Palmstierna to reach a wide audience. He was also sure that there was great interest in London in Sweden's National Environment Protection Board, this 'totally unique initiative'. ${ }^{73}$

Palmstierna was interested and suggested that an event could be held in conjunction with his trip to the Netherlands towards the end of the year. William-Olsson quickly replied and again regretted the Society's poor finances. He stressed that an appearance 'would be such a definite Swedish interest' that it should be possible to obtain funding. Perhaps from the National Environment Protection Board or the embassy? He added that it was not 'completely unthinkable' that some form of appearance on the BBC might result. $\mathrm{He}$ could not promise anything, but intended to invite 'selected members of the press'. ${ }^{74}$

The type of chain reaction that William-Olsson hoped for in London occurred in Finland in August. Following an appearance in Helsinki, Palmstierna was contacted by the television editor Lauri Markos. He explained that Palmstierna's lecture had made a strong impression on him and that a programme was now being planned for Finnish television about the threats to the human habitat. Markos was particularly interested in the dangers that 'can be found in various foods' and wondered if Palmstierna could help to turn the programme idea into reality. ${ }^{75} \mathrm{~A}$ few weeks later, Teuvo Suominen of the Finnish Nature Conservation Society wrote to Palmstierna. Together with Vaasa Summer University, the Society planned 'to organize a week for environmental protection' in the summer of 1969. He would like to invite Palmstierna as a speaker, and he also wondered if it might be possible to bring in the exhibition $\ddot{A} n$ sen då? In conclusion, he said that Plundring, svält, förgiftning had attracted great attention in Finland and he hoped it would soon be

73 Letter from H. William-Olsson to Hans Palmstierna, 5 August 1968, 452/3/3 (HP ARBARK).

74 Letter from H. William-Olsson to Hans Palmstierna, 25 August 1968, 452/3/3 (HP ARBARK).

75 Letter from Lauri Markos to Hans Palmstierna, 26 August 1968, 452/3/3 (HP ARBARK). 
translated. 'We are very impressed here by the new generation of Swedish prophets who have arisen, individuals like Rolf Edberg, Nils Landell, Gunnar Myrdal, yourself, etc. ${ }^{76}$

In Denmark, too, people were starting to become aware of Hans Palmstierna. In the early autumn of 1968, his book was favourably reviewed in the Copenhagen-based morning newspaper Politiken. Its editor, Harald Mogensen, wondered if Palmstierna himself would be interested in writing a column for the newspaper. ${ }^{77}$ Palmstierna immediately said yes. ${ }^{78}$ Mogensen explained that in Denmark, they 'had not really had a comprehensive debate about the immense scope and significance of the pollution problems'. Occasionally there were small discussions, but 'the big perspective has, as it were, not been fully outlined'. He hoped that a column by Palmstierna could change that. ${ }^{79}$ In addition to Mogensen, the youth wing of the Danish Social Democratic Party also contacted Palmstierna to invite him to speak to them. He told them about 'the educational activity that exists in the field of environmental protection in Sweden'. He singled out Folksam's campaign and encouraged the Danish young people to contact Anders Ericsson. ${ }^{80}$ Nordic interest in the campaign grew to a considerable level. At the beginning of 1969, conferences were held in Copenhagen and Oslo at which Hans Palmstierna and Folksam spoke about the Swedish initiative. The Folksam campaign became a model for similar campaigns in Denmark, Norway, and Finland. ${ }^{81}$

\section{The environmental awakening in Sweden}

The greatest interest in environmental issues, as well as in Hans Palmstierna, was found in Sweden, however. In August 1968, an anonymous light-hearted article in Dagens Nybeter portrayed him as 'the revivalist preacher'. The writer described how jealousy was

76 Letter from Teuvo Suominen to Hans Palmstierna, September 1968, 452/3/3 (HP ARBARK).

77 Letter from Harald Mogensen to Hans Palmstierna, 27 September 1968, 452/3/3 (HP ARBARK).

78 Letter from Hans Palmstierna to Harald Mogensen, 30 September 1968, 452/3/3 (HP ARBARK).

79 Letter from Harald Mogensen to Hans Palmstierna, 7 October 1968, 452/3/3 (HP ARBARK).

80 Letter from Hans Palmstierna to Görgen Christiansen, 11 October 1968, 452/3/3 (HP ARBARK).

81 Anon., 'Nordisk front mot miljöförstöring', Folksam, 4 (1969), p. 31. 
sweeping the scientific world and fury was now simmering among the industrial and municipal big shots: 'And all this while almost all the rest of the Swedish people just want to have more Palmstierna.' He had 'offers for far more than 365 speeches a year' and was constantly on the move. But why 'this tidal wave of Palmstierna through all our media?' The writer of the article explained that Plundring, svält, förgiftning had appeared at just the right time. Palmstierna himself had a 'gentle voice' and managed to be 'placid and amiable' even though he 'preached terrible truths'. In addition, he was able to play 'on the entire communication apparatus'. But could he really continue to keep up this pace? Was he not out and about a little too often? ${ }^{82}$

The humourist's questions came to a head in the autumn of 1968. The 'front against environmental destruction' had been launched in earnest and the Social Democrats' campaign for the upcoming Riksdag election was intensifying. Palmstierna declined to stand for a seat in the Riksdag himself, but he lent his name to the campaign and spoke at rallies. In a large published advertisement, he explained that 'as a scientist with some degree of insight into humanity's problems and future, one cannot but take a political stand'. In a world of overpopulation, oppression, environmental destruction, lust for power, and commercialism, it was impossible just to stand by. The great enemy was self-interest; the answer, solidarity. 'A socialism with open dialogue and free discussion of the problems and their solutions then becomes the self-evident option. That is why I am a Social Democrat. ${ }^{83}$

Letters from the public continued to pour in. Gunilla Brotaeus, a student, wrote that she was 'fully aware of what a busy person' she was bothering, but she still hoped that 'someone who so stubbornly spreads his message cannot be completely uninterested in the fish that bite'. Brotaeus wrote that she was studying English at Stockholm University and was in the process of writing an essay on environmental destruction. Unfortunately, she wrote, she did not believe that she had sufficiently comprehensive material, particularly regarding the economic aspects. She therefore wondered if Palmstierna could help her disseminate the facts 'even though it be on a small scale'. ${ }^{84}$ Palmstierna thanked her for her interesting letter but did not send

82 Anon., 'Hans Palmstierna, väckelsepredikanten', DN, 11 August 1968.

83 Anon., 'Egennyttan den stora fienden', DN, 1 September 1968.

84 Letter from Gunilla Brotaeus to Hans Palmstierna, September 1968, 452/3/3 (HP ARBARK). 
her any information, advising her instead to contact Professors Erik Dahmén and Birgitta Odén, plus Anders Ericsson at Folksam. ${ }^{85}$

That same day, Mats Börjesson in Umeå received a similar reply. He represented the city's newly formed development group and informed Palmstierna that the Museum of Västerbotten had bought the rights to show the exhibition $\ddot{A} n$ sen $d \dot{a}$ ? . It would be in Umeå during the month of October and then tour the Västerbotten province. In conjunction with this, the group was planning 'to conduct an elementary information campaign in order to involve more people'. Could Palmstierna possibly write something for the newspaper Västerbottens folkblad and come to Umeå and speak at some point during that autumn? ${ }^{36}$ He could not - he was fully booked all autumn. He suggested that Börjesson should contact Lennart Danielsson at the National Environment Protection Board or Associate Professor Göran Löfroth at the Department of Radiation Biology at Stockholm University. As for himself, he declined 'with sadness in my heart, because I know how committed you and the people around you are'. ${ }^{87}$

One of those people was upper-secondary-school teacher Kerstin Hägg. She explained that Georg Borgström had recently been to Umeå and given a lecture to teachers and pupils. While 'most people still have the terrible realities that Borgström presented to us fresh in their memory', she hoped to launch a campaign that could benefit developing countries. Hägg's idea was that all the teachers at her school would set aside 'a small part of their large salaries' for this purpose. The problem was to find 'a project that as many people as possible can accept'. She was considering international family planning organizations, but wondered whether Palmstierna had any other idea? She said he had done a lot to raise her own awareness, singling out a lecture he had given in Umeå in the autumn of 1966. It had been 'something of a "wake-up call"' for her, and she now hoped that she could 'spread my little insight further' to acquaintances and pupils. Never before had she felt that the teaching profession was so very important. ${ }^{88}$

85 Letter from Hans Palmstierna to Gunilla Brotaeus, 30 September 1968, 452/3/3 (HP ARBARK).

86 Letter from Mats Börjesson to Hans Palmstierna, 20 September 1968, 452/3/3 (HP ARBARK).

87 Letter from Hans Palmstierna to Mats Börjesson, 30 September 1968, 452/3/3 (HP ARBARK).

88 Letter from Kerstin Hägg to Hans Palmstierna, 7 September 1968, 452/3/3 (HP ARBARK). 
Palmstierna was pleased by the letter and answered it at length. Stressing the importance of 'making people as aware of the problems as possible', he said that trying to 'enlighten the entire population' was not a reasonable endeavour. The way forward was 'to start by focusing on particular groups'. His own immediate goal was to cause 'a change of heart' among the people who prepared the ground for political decisions. The attitude of the decision-makers themselves was much harder to change. Palmstierna considered Folksam's campaign to be one stage of this work, and he encouraged Hägg to contact Anders Ericsson. She could thereby play a leading role in the work towards change. With regard to Hägg's fundraising proposal, he was positive but brief. In his view, the key to long-term success was primarily found in shaping opinion and changing attitudes. ${ }^{89}$

The growing interest in the environment found in Umeå is also evident in a letter from a man named Lars Gustafsson. He wrote to Palmstierna informing him that 200 people had helped to found the city's development group. Its activities were divided into ten action-and-study subgroups. Gustafsson himself represented the subgroup focusing on 'the destruction of nature and the environment'. He explained that his group was reaching out by giving speeches in schools and workplaces, holding demonstrations, and putting pressure on politicians. But he was also keen for the group to identify particular issues on which to focus its efforts. He himself was heavily involved in 'bringing about a ban on non-returnable glass' and therefore turned to Palmstierna with seven specific questions. ${ }^{90}$ Once again, Palmstierna encouraged the letter-writer to contact Anders Ericsson at Folksam and sought to channel the public's involvement via the 'Front against environmental destruction'. ${ }^{91}$

Palmstierna himself no longer had enough time to deal with all the inquiries. At the beginning of the year, he had spoken at church services and local Rotary clubs. ${ }^{92}$ By the autumn of 1968 , however, he was saying 'no' to almost everything. The upper-secondary-school

89 Letter from Hans Palmstierna to Kerstin Hägg, 30 September 1968, 452/3/3 (HP ARBARK).

90 Letter from Lars Gustafsson to Hans Palmstierna, 26 September 1968, 452/3/3 (HP ARBARK).

91 Letter from Hans Palmstierna to Lars Gustafsson, 4 October 1968, 452/3/3 (HP ARBARK).

92 Letter from Vällingby Rotary Club to Hans Palmstierna, 28 December 1967, 452/3/2 (HP ARBARK); Letter from Sven Volk to Hans Palmstierna, 11 February 1968, 452/3/3 (HP ARBARK). 
pupils at Östra Real School in Stockholm, the doctors at Jönköping County Hospital, the business leaders of the Halland County marketing association, and the initiators of International Week in Malmö all received the same negative answer as Umeå's development group. ${ }^{93}$ However, Lars Emmelin in Lund did receive Palmstierna's active support. Emmelin was the driving force behind the student initiative that had led to the creation of Sweden's first course on environmental protection. The newspaper Arbetet reported that there had been many applications. Only 50 of the 200 applicants had been accepted. At the beginning of October, the course began with its formal lead instructor and examiner - Hans Palmstierna - coming to Lund and giving an introductory lecture. ${ }^{94}$ In the autumn of 1968 , the [trade-union movement's] Workers' Education Association (ABF) also began giving courses based on Palmstierna's book, and [the Liberal and Centre Party adult-education association] Studieförbundet Vuxenskolan launched the course 'Framtidsmiljön' [The environment of the future $].^{95}$ By this time, Plundring, svält, förgiftning had sold 29,000 copies and been published in a fifth edition. ${ }^{96}$

One year after environmental issues had made their major breakthrough in Sweden, the so-called environmental awakening was a fact. Knowledge of a global environmental crisis was not only circulating in the public sphere; it was part of many people's lives. One sign of the times was the publication on 30 September 1968 by Dagens Nyheter of a two-page spread entitled: 'Det här kan vi alla göra för miljövården' [This is what we can all do towards environmental protection]. The journalist, Gun Leander, suggested various ways in which consumers could make good environmental choices, such as drinking beer from recyclable bottles, washing dishes by hand, using low-octane petrol in their cars, and having composting toilets in their country cottages. Most important, though, was that 'we ourselves

93 Letter from Hans Palmstierna to Lennart Blomdahl, 20 September 1968, 452/3/3 (HP ARBARK); Letter from Hans Palmstierna to Ragnhild Billig, 20 September 1968, 452/3/3 (HP ARBARK); Letter from Hans Palmstierna to Jonas Ljungberg, 30 September 1968, 452/3/3 (HP ARBARK); Letter from Hans Palmstierna to Karl Eriksson, 30 September 1968, 452/3/3 (HP ARBARK).

94 Anon., '50 av 200 kom med på miljövårdskurs i Lund', Arbt, 2 October 1968. The origins and history of the course are described in detail in an unpublished manuscript which Lars Emmelin allowed me to read.

95 Torsten Sandberg, Framtidsmiliön: En studieplan från studieförbundet Vuxenskolan (Falköping: Studieförbundet Vuxenskolan, 1968).

96 Advertisement for Plundring, svält, förgiftning, SvD, 9 November 1968. 
get involved and force our politicians to act'. Environmental issues were primarily the concern of citizens, not of consumers. That said, there were many opportunities 'for everyone with an environmental conscience' to work for change in daily life as well. ${ }^{97}$ The beginning of 1969 saw the first regular opinion polls measuring the Swedish public's attitude to environmental destruction. ${ }^{98}$

The swarm of activities we have encountered in this chapter can hardly be characterized as an organized environmental movement. No such thing existed in Sweden or anywhere else at this time. By the beginning of the 1970s, though, the situation was different. That was when a number of new organizations of varying size and importance were founded. They included successful international networks such as Friends of the Earth and Greenpeace. But during the Swedish breakthrough phase of 1967 to 1968, environmental issues were being pursued within and via established organizations. Traditional nature-conservation associations form a particularly intriguing prism for studying this process. They possessed a longcultivated commitment to protecting animals, nature, and the wilderness from the advance of modern civilization. What happened to that commitment when the environmental awakening occurred? Did operations change in the established organizations? Or did most things stay the same? With a view to answering those questions, the next chapter examines the youth organization Nature and Youth Sweden (Fältbiologerna).

97 Gun Leander, 'Det här kan vi alla göra för miljövården', DN, 30 September 1968.

98 Lennart Lundqvist, Miljövårdsförvaltning och politisk struktur (Uppsala: Verdandi, 1971), pp. 106-107; Bennulf, Miliöopinionen i Sverige, p. 56. 